\title{
KOHESIVITAS KELOMPOK DALAM KOMUNITAS XTC (PAC CIMENYAN) PIMPINAN ANAK CABANG CIMENYAN
}

\author{
Derina Herman ${ }^{1}$, Nela Widiastuti ${ }^{2}$ \\ Fakultas Ilmu Komunikasi Universitas Adhirajasa Reswara Sanjaya (ARS) Bandung \\ Email: Derinaherman97@gmail.com
}

\begin{abstract}
ABSTRAK
Proses komunikasi kelompok sangat penting untuk mencapai kohesivitas kelompok. Dalam kelompok harus muncul kesadaran kolektif sebagai anggota kelompok sehingga antara sesama anggota kelompok tumbuh perasaan-perasaan atau sentiment atas dasar kesamaan sehingga tercipta komunikasi yang interaktif dan bisa mencapai tujuan bersama dalam kelompoknya. Tujuan penelitian ini untuk mengetahui kohesivitas di kalangan anggota XTC (PAC Cimenyan) dalam upaya menjaga eksistensi kelompok. Metode yang di gunakan dalam penelitian ini adalah metode kualitatif dengan pendekatan studi kasus. Teknik pengambilan data melalui observasi dan wawancara mendalam bersama anggota komunitas XTC (PAC Cimeyan). Teknik pemeriksaan ke absahan data dengan triangulasi dan mengunakan teori activity interaction sentiment. Penelitian ini menunjukan bahwa kohesivitas kelompok terbentuk dari kebersamaan kelompok seperti proses menumbuhkan perasaan atau sentiment-sentimen pada saat berkumpul. Inilah yang menyebabkan kohesivitas dalam komunitas XTC (PAC Cimenyan) dan membuat komunitas ini mampu menjaga eksistensinya diantara komunitas sejenis lainnya.
\end{abstract}

Kata Kunci: Tayangan televisi, analisis interaktif, kontroversional

\section{GROUP COHESIVITY IN XTC COMMUNITY (PAC CIMENYAN) CHILDREN OF THE CIMENYAN BRANCH)}

\begin{abstract}
The process of group communication is very important to achieve group cohesiveness. In groups, collective awareness must emerge as a group member so that among fellow group members grow feelings or sentiments on the basis of equality so that interactive communication can be created and can achieve common goals within the group. The purpose of this study was to determine cohesiveness among members of XTC (PAC Cimenyan) in an effort to maintain the group's existence. The method used in this research is a qualitative method with a case study approach. Data collection techniques through observation and in-depth interviews with members of the XTC community (PAC Cimeyan). Examination techniques to the validity of the data by triangulation and using activity interaction sentiment theory. This research shows that group cohesiveness is formed from group togetherness such as the process of growing feelings or sentiments when gathering. This is what causes cohesiveness in the XTC community (PAC Cimenyan) and makes this community able to maintain its existence among other similar communi
\end{abstract}

Keywords: Television shows, interactive analysis, controversial 
Korespondensi: Derina Herman. Program Studi Ilmu Komunikasi, Universitas Adhirajasa Reswara Sanjaya (ARS) Jl. Sekolah Internasional No. 1-2, Cicaheum, Kota Bandung, Jawa Barat 40282 No. HP : 0895343171754, Email : derinaherman97@gmail.com

\section{PENDAHULUAN}

Pertumbuhan geng motor di Indonesia mengalami perkembangan yang sangat pesat. Hal ini merupakan sebuah realita yang dihasilkan dari perkembangan social masyarakat yang semakin heterogen. Selain faktor pertumbuhan geng motor yang sangat pesat, faktor kebutuhan interpersonal untuk mengesistensikan diri di dalam pergaulan sehari hari menjadi faktor lain terbentuknya kelompok kelompok geng. Dari sini masyarakat dalam hal ini pemilik atau pengguna motor mulai mencari wadah atau tempat untuk menyalurkan hobinya yang kemudian membentuk kelompokkelompok pecinta motor atau lebih di kenal dengan komunitas gang motor.

Suatu fenomena di masyarakat yang akhirakhir ini muncul ke permukaan, menimbulkan polemik mengenai keberadaan suatu kelompok , dimana kelompok ini berkaitan dengan hal yang masih dianggap tabu dikalangan masyarakat kita. Secara umum orang-orang menyebutnya dengan istilah gangster (kelompok orang yang mempunyai kegemaran berkelahi atau membuat keributan), fenomena yang terjadi dan dilakukan oleh gangster ini menjadi suatu persoalan yang diperbincangkan dalam konteks kehidupan bermasyarakat terkait perilakunnya yang menyimpang dari nilai dan norma.

Mengetahui pertumbuhan gang motor yang meningkat tiap tahunnya maka telah banyak muncul berbagai macam kelompok geng di kota Bandung. Salah satunya merupakan kelompok XTC (PAC Cimenyan) yang merupakan kelompok berasaskan komunitas. Dalam proses pembentukan sebuah komunitas biasanya komunikasi dan interaksi yang terjadi bersifat horizontal karena dilakukan oleh individu-ivdividu yang kedudukannya setara. Tanpa adanya interaksi, mustahil komunitas mampu mencapai tujuannya. Oleh karenanya di dalam sebuah komunitas dapat di temukan adanya interaksi dengan pola yang relatif stabil, kerjasama di antara anggota, dan adanya pertukaran pendapat dalam pembuatan keputusan dan pengambilan tindakan.

Awal berdirinya XTC (PAC Cimenyan) bermula dari suatu kepedulian dari individu yang telah menjadi anggota XTC dan ingin mengembangkan di wilayah Kec Cimenyan. Berdiri pada tanggal 30 Desember 2017 dan keluar surat keterangan (SK), XTC PAC Cimenyan dari dewan pimpinan cabang (DPC), Kab Bandung yang di tandatangani oleh Dadin Khadir Djaelani sebagai ketua dewan pimpinan cabang (DPC) Kab Bandung pada tanggal 21 Februari 2017 atas persetujuan dari dewan pimpinan daerah (DPD) dan dewan pimpinan pusat (DPP). Setelah turun SK XTC (PAC Cimenyan) yang mempunyai visi dan misi serta tujuan yang sama, XTC PAC Cimenyan merupakan komunitas motor yang terdiri dari anggota yang memiliki hobi yang sama yaitu berkendara motor, balap motor dan memliki kesamaan dalam memodifikasi motornya. XTC PAC Cimenyan adalah salah satu bentuk dari komunitas karena para anggota dalam komunitas tersebut terkait pada suatu kepentingan, yaitu kepentingan komunitas. Menurut Rakhmat (2009. Kohesivitas Kelompok Dalam Komunitas XTC (Pac Cimenyan) Pimpinan Anak Cabang Cimenyan 
h.141) menjadi suatu komunitas diperlukan kesadaran anggota anggotanya akan ikatan yang sama, yang mempersatukan mereka. Adanya ikatan di antara para anggota menimbulkan komunikasi dan interaksi baik secara personal maupun sosial.

XTC PAC Cimenyan, sebagai cabang komunitas XTC di wilayah Cimenyan juga telah menunjukkan eksistensinya melalui berbagai kegiatan kegiatan yang dilakukannya seperti, pada saat ini pendapatan anggota program sosial kepedulian komunitas terhadap lingkukang setempat. Jumlah anggota komunitas XTC PAC Cimenyan sekarangpun mecapai 80 orang dan yang tercatat aktif sebanyak 58 anggota. Seperti komunitas lainnya, untuk bergabung dan terlibat dalam komunitas ini tentu ada beberapa syarat yang wajib di penuhi yaitu izin dari orang tua/wali (tanda tangan orang tua/wali), menyertakan foto ktp atau kartu pelajar dan kartu keluarga, perdomisili Kec Cimenyan minimal umur 15 tahun.

Selain itu, para anggota yang tergabung dalam XTC PAC Cimenyan memiliki rasa saling memiliki dan siap membantu kapanpun sesuai dengan hakikatnya komunitas itu sendiri yang dapat dijadikan sebagai tempat para anggota untuk berkeluh kesah tentang motornya, memberi berbagai informasi tentang motornya kepada anggota lain, dan terutama tempat penyaluran hobi mereka. Komunitas ini juga memliki tujuan dan aturan dalam berkelompok untuk saling memahami satu dengan yang lainnya dengan bermacam komunikasi baik itu verbal maupun nonverbal. Atas dasar kesamaan hobi yang menjadikan komunitas ini memiliki kohesivitas tersendiri di dalamnya.
Komunitas adalah sekelompok manusia yang hidup dan bekerja sama cukup lama, sehingga mereka dapat mengatur diri mereka dan menganggap diri mereka sebagai suatu kesatuan sosial dengan batas-batas yang dirumuskan dengan jelas. Komunitas dalam bahasa inggris di sebut commumity yang bila di terjemahkan dalam bahasa Indonesia berarti masyrakat setempat. Istilah komunitas biasanya di gunakan untuk menunjuk pada kelompok kelompok sosial.

Dalam kehidupan sosial bermasyarakat, keberadaan kelompok-kelompok atau komunitas tidak dapat di pisahkan dari kehidupan social manusia. Individu membutuhkan kelompok dalam pergaulan sehari-harinya yang memiliki visi dan misinya serta tujuan yang sama, karena pada hakikatnya menurut Mulyana (2012, h.82) kelompok adalah sekumpulan orang yang mempunyai tujuan bersama yang berinteraksi satu sama lain untuk mencapai tujuannya, mengenal satu sama lain, dan memandang individu sebagai bagian dari kelompok tersebut. Bertahannya suatu kelompok di karenakan hubungan komunikasi yang terjalin dengan baik dan kesedaran bersama dari para anggota akan adanya suatu ikatan yang mempersatukan mereka.

Menurut Forsyth (2006), interpersonal attraction (keterkaitan interpersonal) suatu kelompok bisa terjalin saat dalam kelompok tersebut ada keterkaitan dari setiap individu. Selain ketertarikan, faktor yang mempengaruhi pembentukan kelompok di antaranya kedekatan, frekuensi, interaksi, kesamaan, kelengkapan, timbal balik dan saling memberikan penghargaan. Dengan begitu juga mereka bisa membentuk 
kelompoknya yang belum sempurna menjadi kelompok yang sangat kompak.

Schachter, \& Back (1950) Sarwono (2012, h.164) menjelaskan bahwa kohesivitas adalah mengenai penyatuan kekuatan Festinger mendefinisikan kohesivitas sebagai kekuatan yang berasal dari anggota-anggota kelompok yang tetap bertahan pada kelompok tersebut. Konsep tersebut menggambarkan kohesivitas sebgai kekuatan “daya tarik" yang menjaga agar para anggotanya tetap bersatu. Aplikasinya pada sebuah komunitas, kohesivitas adalah kekuatan dari pemersatu yang menghubungkan anggota komunitas secara individual dengan anggota yang lainnya. Kebersamaan dan kerja sama antar anggota komunitas yang memiliki rasa kesatuan dan saling bergantung untuk mendukung keberhasilan dari tujuan yang ingin dicapai menimbulkan kohesivitas dalam komunitas.

Dari uraian di atas bahwa kohesivitas dari komunitas ini terlihat dari dikarenakan XTC PAC Cimenyan merupakan komunitas otomotif jadi setiap anggota mempunyai kesamaan tujuan untuk memperdayakan kemajuan di bidang otomotif sebagai contoh, memodifikasi motor untuk di ikut sertakan dalam kontes modifikasi motor, memperdayakan potensi-potensi anggota XTC PAC Cimenyan unuk meraih prestasi dalam bidang balap motor road race atau dragrace dan sosial sering terhadap teknologi-teknologi baru dalam dunia otomotif khusus teknologi-teknologi yang di terapkan ke sepedah motor.

Alasan individu bergabung pada komunitas XTC PAC Cimenyan, ketertarikan terhadap solidaritas komunitas tersebut terhadap satu sama lain dengan menjungjung tinggi jiwa corsa (jiwa kepedulian sesama anggota yang kuat), mempunyai daya tarik terhadap dunia otomotif, ingin belajar menjadi pembalap atau menjadi mekanik dan menambah pengalaman dalam komunitas.

Tujuan penelitian ini untuk mengetahui kohesivitas di kalangan anggota XTC (PAC Cimenyan) dalam upaya menjaga eksistensi kelompok. Metode yang di gunakan dalam penelitian ini adalah metode kualitatif dengan pendekatan studi kasus. Teknik pengambilan data melalui observasi dan wawancara mendalam bersama anggota komunitas XTC (PAC Cimeyan). Teknik pemeriksaan ke absahan data dengan triangulasi dan mengunakan teori activity interaction sentiment.

\section{METODE PENELITIAN}

Perspektif penelitian yang digunakan oleh seorang peneliti adalah kualitatif yang memiliki tahapan berfikir kritis-ilmiah, yang mana seorang peneliti memulai berfikir secara induktif, yaitu menangkap berbagai fakta atau fenomenafenomena sosial, melalui pengamatan di lapangan, kemudian menganalisisnya dan kemudian berupaya melakukan teorisasi berdasarkan apa yang diamati itu (Berutu dalam Bungin, 2013).

Pendekatan penelitian kualitatif adalah metode penelitian yang berlandaskan pada filsafat postpositivisme. Filsafat ini sering juga disebut sebagai paradigma interpretif dan konstruktif, yang memandang realitas social sebagai sesuatu yang utuh, kompleks, dinamis, penuh makna, dan hubungan gejala bersifat interaktif. 
Pada penelitian ini, peneliti menggunakan paradigma post positivistik. Menurut Denzin \& Lincoln (2009, h.6) post positivistik didasarkan pada logika deduktif dan jenis pemaparannya adalah laporan ilmiah. Post positivistik percaya sesuatu dikatakan ada berdasarkan objektivitas dan secara kontekstual. Post positivistik bertujuan untuk menemukan kemungkinan kebenaran, mencari anomali realitas, dan menemukan faktorfaktor baru untuk melengkapi teori lama atau bahkan menemukan teori baru karena ilmu pengetahuan bersifat terus bergerak.

Penelitian ini menggunakan post postivistik karena realitas tentang kohesivitas dalam komunitas XTC PAC Cimenyan dan orientasi dalam penelitian ini adalah menemukan faktorfaktor yang bisa membuat komunitas XTC PAC Cimenyan memiliki kohesivitas kelompok di kalangan anggotanya sehingga eksistensi kelompok semakin meningkat.

Pendekatan penelitian ini menggunakan penelitian kualitatif. Penelitian kualitatif memiliki beberapa definisi, di antaranya yang diberikan oleh Williams (1995) yang menulis bahwa penelitian kualitatif adalah pengumpulan data pada suatu latar ilmiah, dengan menggunakan metode alamiah dan dilakukan oleh orang atau peneliti yang tertarik secara alamiah (Moleong, 2010, h.4). Masih dalam buku yang sama, Denzin dan Lincoln (2009, h.2) pun menyatakan bahwa penelitian kualitatif adalah penelitian yang menggunakan latar alamiah, dengan maksud menafsirkan fenomena yang terjadi dan dilakukan dengan jalan melibatkan berbagai metode yang ada.
Dari penjelasan di atas dapat disimpulkan pendekatan kualitatif merupakan pendekatan yang berdasarkan pada kenyataan lapangan dengan kondisi realitas lapangan atas apa yang dialami, dirasakan, dan digambarkan responden yang akhirnya dicari rujukan teorinya.

Tujuan dari kualitatif bukan saja kebenaran, namun pemahaman subjek terhadap dunia sekitarnya. Hasil dari penelitian kualitatif diharapkan dapat menghasilkan data serta berbagai informasi yang bermakna seputas realitas sosial pada komunitas geng motor di Kota Bandung, khususnya pada komunitas XTC PAC Cimenyan itu sendiri.

Dalam penelitian ini, penulis menggunakan metode yang relevan yaitu dengan menggunakan pendekatan penelitian kualitatif dengan metode studi kasus. Menurut Yin (2012, h.1) metode studi kasus adalah strategi yang lebih cocok bila pokok pertanyaan suatu penelitian berkenaan dengan "how" dan "why".

Dari pendapat di atas, penulis memahami bahwa metode penelitian studi kasus dibuat guna menjawab pertanyaan-pertanyaan awal yaitu pada pertanyaan seperti “ mengapa " atau " bagaimana "pada fokus penelitian sehingga akan mempermudah peneliti ke tahap pengumpulan dan analisis data.

Dari beberapa uraian di atas, peneliti menginterpretasikan bahwa studi kasus dalam penelitian kualitatif merupakan cara atau metode yang sesuai untuk menjawab fenomena suatu permasalahan penelitian lebih mendalam terhadap suatu objek penelitian. Dalam kaitannya dengan penelitian ini yaitu penulis ingin memahami 
komunitas, anggota komunitas, kegiatan komunitas, dan hubungan komunitas dengan dunia luarnya. Selain itu penulis memilih untuk menggunakan studi kasus adalah karena komunitas ini memiliki keunikan dalam menjaga kekompakkan di antara anggotanya sehingga mereka menganggap komunitas ini sebagai keluarga lain di luar keluarganya sendiri yang dapat membantu komunitas ini menjaga eksistensi kelompoknya di antara kelompok sejenis lainnya.

\section{HASIL DAN PEMBAHASAN}

Kelompok atau dalam penelitian ini dinamakan Komunitas XTC PAC Cimenyan merupakan kumpulan dari dua orang atau lebih yang berinteraksi dan mereka saling bergantung (interdependent) dalam rangka memenuhi kebutuhan hobi dan tujuan bersama, menyebabkan satu sama lain saling mempengaruhi. Hal ini sejalan dengan pendapat Forsyth (2010) mengatakan bahwa kelompok adalah dua atau lebih individu yang dihubungkan dengan dan dalam hubungan social. Didalam sebuah kelompok memiliki suatu kohesivitas yang terjadi di sebuah kelompok.

Kohesivitas kelompok dalam Komunitas XTC PAC Cimenyan dilihat dari kualitas hubungan anggota dalam kelompok yang sangat erat dan selalu menjaga kebersamaan, mempertahankan keanggotaan mereka dalam kelompok, yang di dukung oleh sejumlah kekuatan kebersamaan, tetapi banyak lebih terfokus pada ketertarikan antar anggota hobi yang sama. Hal ini sesuai dengan pendapat Carron, Brawley, dan Widmeyer (in press, dalam Prapavessis \& Carron, 1997) menjelaskan kohesivitas kelompok merupakan proses dinamis yang tercermin dalam kecenderungan kelompok untuk tetap bersama dan menjaga kebersamaan dalam mengejar tujuan dasar kelompok dan atau untuk pemenuhan kebutuhan afektif anggota kelompok.

Kohesivitas kelompok dalam komunitas XTC PAC Cimenyan merupakan proses dinamis yang tercermin dalam kecenderungan kelompok untuk tetap bersama dan menjaga kebersamaan dalam mengejar tujuan dasar kelompok dan atau untuk pemenuhan kebutuhan afektif anggota kelompok terkait hobi yang mereka miliki. Menurut (Forsyth, 2010) Ada beberapa faktor yang mampu membentuk kohesivitas kelompok, yakni daya tarik antar pribadi, kestabilan anggota kelompok, ukuran kelompok, struktur yang dimiliki, permulaan kelompok. Dalam penelitian ini, peneliti menggali data terkait kohesivitas yang ada dalam komunitas XTC PAC Cimenyan.

Ciri - ciri komunitas XTC PAC Cimenyan memiliki kohesivitas dapat dilihat dari beberapa ciri, yakni memiliki identitas dalam kelompoknya, setiap anggota kelompok memiliki tujuan dan sasaran atau hobi yang sama, setiap anggota kelompok merasakan keberhasilan dan kegagalan yang sama, setiap anggota kelompok saling bekerja sama dan gotong royong, setiap anggota kelompok memiliki tugas dan fungsi atau peran keanggotaan, dan dalam mengambil keputusan selalu diadakan musyawarah kelompok. Ciri kohesivitas dalam komunitas XTC PAC Cimenyan tersebut sesuai dengan pendapat Suryabrata (2007) menyatakan bahwa ciri - ciri kohesivitas kelompok dapat dilihat dari setiap anggota kelompok mengenakan identitas yang sama, setiap anggota kelompok 
memiliki tujuan dan sasaran yang sama, setiap anggota kelompok merasakan keberhasilan dan kegagalan yang sama, setiap anggota kelompok saling bekerja sama dan berkolaborasi, setiap anggota kelompok memiliki peran keanggotaan, dan kelompok mengambil keputusan secara efektif. Untuk mengambarkan kohesisivitas yang terjadi didalam komunitas XTC PAC Cimenyan peneliti akan membahas dari hasil penelitian yang telah peneliti analisis sesuai dengan aspek - aspek dalam mengukur kohesivitas sebuah kelompok dalam komunitas XTC PAC Cimenyan, sebagai berikut:

\section{Motivasi dan Ketertarikan Individu menjadi bagian Komunitas XTC PAC Cimenyan \\ Dengan menggunakan teori activity} interaction sentiment, peneliti menafsirkan makna tindakan atau motif para informan ke dalam dua bagian yaitu pertama, motif awal para informan sebelum menjadi anggota XTC PAC Cimenyan dan Kedua, adalah motif lanjutan para informan setelah menjadi anggota XTC PAC Cimenyan. Motif tindakan ini ditafsirkan dengan memahami pengalaman-pengalaman para informan sebagai penggemar motor, otomotif dan organisasi pada umumnya, dan sebagai anggota XTC PAC Cimenyan khususnya.

Peneliti dapat melihat kegiatan-kegiatan secara langsung terhadap kelompok XTC PAC Cimenyan. Secara individu kelompok tersebut mempunyai tujuan dan kesamaan hobi yang sama dari segi otomotif, organisasi, dan merubah ke arah yang lebih baik. Secara keseluruhan pada setiap individu dapat mengembangkan kreatifitas yang di wadahi oleh komunitas XTC PAC Cimenyan tersebut.
Individu akan lebih tertarik melihat dari segi kelompok kerjanya sendiri dari pada melihat dari anggotanya secara spesifik. Daya Tarik ini dapat berupa semangat kerja yang dimilik kelompok XTC PAC Cimenyan sehingga akan berdampak positif terhadap perkembangan dan keberlangsungan kelompok tersebut untuk dapat mencapai tujuan.

XTC PAC Cimenyan dapat terjalin ketika dalam sebuah kelompok tersebut ada ketertarikan dari setiap individu. Faktor yang mempengaruhi pebentukan komunitas XTC PAC Cimenyan selain ketertarikan diantaranya seperti kegiatan, frekuensi interaksi, kesamaan, kelengkapan timbal balik, dan saling memberikan penghargaan dapat mendorong terbentuknya suatu kelompok. Dengan demikian komunitas XTC PAC Cimenyan dapat membentuk kelompok yang belum sempurna menjadi kelompok yang sangat kompak.

Pertanyaan mengenai sudut pandang anggota terhadap komunitasnya sendiri perlu diungkapkan sebab merupakan latar belakang atau motif seseorang sehingga tertarik untuk bergabung pada suatu komunitas (daya tarik in-group). Seorang individu yang tergabung dalam suatu kelompok sosial pasti didasari oleh suatu alasan tertentu yang berasal dari dirinya. Suatu kelompok dapat menarik individu untuk bergabung didalamnya karena tentuada sesuatu yang unik atau menarik untuk diikuti.

Berdasarkan paparan data diatas, dapat disimpulkan bahwa latar belakang proses bergabungnya para anggota, antara lain faktor ketertarikan kepada komunitas XTC PAC Cimenyan yang telah bisa merangkul kebersamaan 
dalam menjalankan komunitas, kemudian yang kedua adalah kecintaan yang sama terhadap motor atau otomotif. Berawal dari latar belakang tersebut inilah yang menjadikan informan bergabung menjadi anggota kelompok XTC PAC Cimenyan.

Pada individu tersebut mempunyai rasa untuk meningkatkan pengetahuan dalam bidang otomotif guna menciptakan persaudaraan yang ditimbulkan dari dasar kesamaan hobi. Setiap individu yang ingin bergabung dalam organisasi tersebut, bahwa terlihat oleh kalangan masyarakat bahwa setiap anggotanya mempunyai kepedulian terhadap anggota dalam bersosialisasi komunikasi, gotong royong, jiwa corsa, kepedulian terhadap sesama yang menjadikan salah satu tertariknya individu dari luar organisasi tersebut untuk bergabung atau undeal pada organisasi tersebut.

\section{Pola Interaksi yang terjadi dalam Komunitas XTC PAC Cimenyan}

Berdasarkan hasil pengamatan dilapangan, peneliti menemukan keempat aspek tersebut dalam keseharian kelompok XTC PAC Cimenyan. Hal ini cukup menandakan bahwa komunikasi punya peran besar dalam membangun kohesivitas yang telah terjalin dalam kelompok XTC PAC Cimenyan. Keempat indicator tersebut seperti menjadi bagian dari keseharian kelompok. Secara alamiah para anggota XTC PAC Cimenyan menjalankan sejumlah indicator komunikasi dalam kelompok yang kohesiv tersebut.

Pertama, pola komunikasi yang ditunjukkan kelompok XTC PAC Cimenyan sangat kompleks. Kompleks dalam hal ini berarti mengandung beberapa unsur yang pelik, rumit, sulit, dan saling berhubungan. Dalam hal ini, peneliti melihat unsur kompleksitas itu terdapat pada proses dan isi dari komunikasi tersebut, salah satunya dilihat dari proses diskusi yang dilakukan kelompok ini. Mereka kerap saling memberikan pandangannya masing-masing terkait suatu masalah dalam sebuah diskusi yang sangat interaktif. Mereka juga tidak jarang terlibat perdebatan panjang sebelum akhirnya mencapai kesepakatan satu sama lain. komunikasi kelompok XTC PAC Cimenyan terjadi dalam berbagai macam kegiatan dan dilaksanakan di berbagai tempat. Bentuk komunikasi kelompok XTC PAC Cimenyan juga tidak hanya terjadi secara linear (top down), melainkan komunikasi terjadi antarasesama pengurus, sesama anggota, antara anggota dengan pengurus dan komunikasi juga berlangsung dengan komunitas gang motor lainnya (group). Komunikasi yang berlangsung pun terjadi secara tidak langsung diantara pengurus dan anggota XTC PAC Cimenyan, yakni dengan perantaraan jejaring media sosial termasuk komunikasi.

Kedua, Peneliti dapat menyimpulkan pola interaksi yang ditunjukan kelompok XTC PAC Cimenyan berjalan atas dasar komunikasi yang efektif hal tersebut ditunjukan karena adanya timbal balik antar si pemberi informasi dan si penerima informasi. Para anggota sangat memahami kebutuhan-kebutuhan kelompoknya termasuk tugas dan peran yang wajib di jalankan masing-masing anggota. Pola interaksi komunikasi yang tercipta dalam komunitas XTC PAC Cimenyan dapat penulis gambarkan sebagai berikut, Bahasa yang sering digunakan untuk berkomunikasi antar anggota XTC PAC Cimenyan adalah bahasa sehari-hari (bahasa daerah "sunda") walaupun kadang ada anggota yang menggunakan 
bahasa campuran antara bahasa daerah dan bahasa Indonesia, pola interaksi dalam komunitas tersebut mempunyai cara berkomunikasi pada umumnya didalam organisasi sesuai hierarki pada struktur organisasi tersebut, contohnya untuk menanyakan perihal otomotif setiap angota langsung menanyakan kepada ketua bidang otomotif dan di posisikan kepada mekanik atau joki balap, contoh kedua untuk menanyakan perihal organisasi XTC PAC Cimenyan tersebut langsung menanyakan kepada pengurus yang bersangkutan.

Ketiga, komunikasi mampu membangun antusiasme yang tinggi para anggota XTC PAC Cimenyan. Hal ini terjadi karena sistem komunikasi diantara anggota XTC PAC Cimenyan berjalan dengan lebih baik dan terarah sehingga berpengaruh bersar terhadap antusiasme setiap anggota kelompok. Dengan kohesivitas yang terjalin itu, anggota XTC PAC Cimenyan merasa lebih nyaman dengan situasi dan kondisi yang tercipta di dalam komunitas XTC PAC Cimenyan. Kenyamanan tersebut menciptakan rasa saling memiliki antar anggota semakin meningkat. Anggota kelompok XTC PAC Cimenyan merasakan bahwa mereka semakin kompak. Selain itu, sebagai anggota juga mengatakan bahwa mereka sering merasa ingin lebih lama berkumpul dengan teman-teman anggota XTC PAC Cimenyan.

Keempat, komunikasi berlangsung dengan intensitas yang tinggi. Rasa nyaman dan saling memiliki diantara anggota XTC PAC Cimenyan juga berimplikasi terhadap intensitas komunikasi dan interaksi yang semakin tinggi. Mereka semakin rajin berkumpul bersama, bukan hanya pada hari berlangsungnya kopdar, melainkan di hari-hari lain saat mereka sama-sama memiliki waktu luang. Mereka juga menambah agenda pertemuan rutin mingguan, misalnya melakukan bakti sosial yang kemudian menjadi ajang untuk lebih mengakrabkan diri dan membuat kekompakkan semakin terjaga.

\section{Bentuk Kohesivitas yang terjadi dalam Komunitas XTC PAC Cimenyan}

Sesuai dengan teori activity interaction sentiment., peneliti mencoba menjelaskan realitas yang terjadi tentang kohesivitas kelompok XTC PAC Cimenyan. Sebagaimana uraian pembahasan terdahulu, peneliti menemukan beberapa aspek yang merepresentasikan realitas tentang kohesivitas dalam kelompok XTC PAC Cimenyan - Meski tidak dapat digeneralisir bahwa semua anggota mengalami fenomena tersebut, setidaknya secara kasuistik telah menunjukkan fakta yang sebenarnya. Beberapa aspek yang dimaksud antara lain; loyalitas individu terhadap kelompok dan solidaritas antaranggota, dan temuan penting lainnya yang perlu dibahas mengenai konflik pada kelompok XTC PAC Cimenyan.

Pertama, loyalitas individu terhadap kelompok. Penulis menemukan kenyataan bahwa anggota XTC PAC Cimenyan memiliki kadar loyalitas dan kesetiaan yang tinggi terhadap komunitasnya sendiri yang dibuktikan dengan kehadirannya disetiap acara atau kopdar, selalu aktif mengikuti setiap kegiatan kelompok XTC PAC Cimenyan. Para informan mengatakan bahwa faktor rasa nyaman menjadi salah satu alasan mereka tidak ingin meninggalkan komunitas XTC PAC Cimenyan. Perasaan seperti ini memang 
wajar terjadi pada kelompok yang memiliki kohesivitas yang tinggi.

Kedua, solidaritas antaranggota. Kohesifitas kelompok merupakan keadaan dimana sebuah kelompok memiliki tingkat solidaritas yang tinggi. Para anggota kelompok mempunyai kesadaran yang tinggi untuk menjaga keutuhan dan keberlangsungan kelompok. Pada realitasnya, para pengurus dan anggota XTC PAC Cimenyan, mengakui bahwa hubungan satu sama lain terjalin baik dan akrab. Berbagai kegiatan dilaksanakan sebagai upaya dari pengurus XTC PAC Cimenyan untuk memupuk rasa kebersamaan, loyalitas dan solidaritas di dalam komunitas XTC PAC Cimenyan. Dapat dikatakan bahwa berbagai macam kegiatan komunitas XTC PAC Cimenyan merupakan instrumen dari tujuan kelompok untuk meningkatkan kohesifitas yang tinggi di dalam kelompok.

Berdasarkan kedua aspek tersebut, maka dapat disimpulkan bahwa kohesivitas yang dibangun melalui komunikasi sangat berpengaruh pada tingkah laku anggota kelompok. Semakin tinggi intensitas komunikasi dalam suatu kelompok, akan membuat semakin tinggi solidaritas dan keterpaduan. Tingginya tingkat solidaritas dan keterpaduan kelompok juga akan membuat semakin tinggi pula rasa saling memiliki antara anggota kelompok. Temuan data penelitian ini sejalan dengan sudut pandang Baron dan Byrne sebagaimana yang diuraikan oleh Rakhmat, bahwa anggota-anggota kelompok merasa terikat dengan suatu kelompok (sense of belonging) yang tidak dimiliki oleh orang yang bukan anggota kelompok. Kemudian nasib anggota-anggota kelompok saling bergantung sehingga hasil setiap orang terkait dalam cara tertentu dengan hasil yang lain.

Munculnya rasa memiliki memang sangat kuat karena mereka merasa kesamaan hobi dan tujuan sama. Rasa persaudaraan karena identitas yang sama sebagai anggota XTC PAC Cimenyan juga telah terbangun karena sense of belonging yang kuat. Komunitas XTC PAC Cimenyan merupakan kelompok yang terbetuk atas dasar kesamaan (orientasi) kecintaan akan suatu hal, maka dari itu beberapa pengurus maupun anggota XTC PAC Cimenyan ini merasa bahwa sense of belonging yang kuat terjalin karena mereka sama-sama mencintai motor dan ingin belajar organisasi. Identitas sebagai anggota XTC PAC Cimenyan kemudian memunculkan rasa kekeluargaan antara mereka sebagai sesama pecinta motor.

\section{SIMPULAN}

Dari hasil penelitian ini didapatkan bahwa kelompok pecinta motor, otomotif dan organisasi merupakan perkumpulan beberapa orang atau lebih yang memiliki kesamaan hobi dan tujuan yaitu untuk menyatukan dan menghidupkan kebersamaan dengan komunitas tentu mempunyai perasaan kesatuaan, tetapi perasaan dalam kesatuaan komunitas XTC PAC Cimenyan ini biasanya amat keras sehingga menimbulkan suatu sentimen persatuan dan tingkat solidaritas yang sangat tinggi menjadikan komunitas XTC tetap utuh.

\section{DAFTAR PUSTAKA}

Alwasilah, A. Chaedar. 2006. Pokonya Kualitatif. Jakarta: Dunia Pustaka Jaya dengan Pusat Studi Sunda.

Braun, V., \& Clarke V. (2006). Using thematic analysis in psychology. Qualitative Research in Psychology. 3 (2), 77-101. Creswell, J.W. (2007). Qualitative Inquiry and Research Design : 
Choosing among five traditions. California : Sage Publications. (online). https://is.vsfs.cz. diakses 10 Januari 2017

Denzin, Norman K. dan Yvonna S. Lincoln (eds). 2009. Handbook of Qualitative Research. Terj. Dariayanto dkk. Jogjakarta: Pustaka Pelajar.

Forsyth, D.R. (1999). Group Dynamics 3rd ed. New York: Brooks/Cole

Forsyth, D.R. (2010). Group Dynamics 5th ed. USA: Cengage Learning

Mulyana, Deddy. 2012. Ilmu Komunikasi Suatu Pengantar, Bandung: PT Remaja Rosdakarya.

Mulyana. Deddy. 2006. Metode Penelitian Kualitatif. Bandung: PT Remaja Rosdakarya.

Moleong, L.J.2010. Metodologi Penelitian Kualitatif, Bandung: Remaja Rosda Karya

Nazir, Moh. 2009. Metode Penelitian. Jakarta: Ghalia Indonesia.

Prapavessis, H., \& Carron, A, V. (1997). Sacrifice, cohesion, and conformity to norms in sport teams. Journal of Group Dynamics: Theory, Research, and Practice, 1, 231-240. doi :10.1037/10892699.1.3.231

Rakhmat, Jalaludin. 2009. Metode Penelitian Komunikasi, Bandung: PT Remaja Rosdakarya.

Robert K. Yin. 2012. Studi Kasus Desain \& Metode, Raja Grafindo Jakarta.

Sugiyono. (2009). Metodologi Penelitian Pendidikan: Pendekatan Kuantitatif, Kualitatif, dan R \& D. Bandung : Alfabeta

Sugiyono. (2012). Memahami Penelitian Kualitatif : Dilengkapi Contoh Proposal dan laporan Penelitian. Bandung : Alfabeta

Treadwell, T., Lavertue, N., Kumar, V. K.., \& Veeraraghavan, V. (2001). The group cohesion scale-revised: Reliability and validity. The International Journal of Action Methods: Psychodrama, Skill Training and Role Playing, 54, 3-12. doi :10.1234/12345678

Wiryanto. 2005. Pengantar Ilmu Komunikasi, Jakarta: Gramedia Widiasarana Indonesia.

Krisyantono, Rachmat. 2007. Teknik Praktis Riset Komunikasi. Jakarta: Kencana. 